\title{
How classical music is embedded in a culture public sphere?
}

\author{
Dr. Juan Wang (International Gender Studies Centre, University of Oxford, UK) \\ juanjudy@hotmail.com
}

\begin{abstract}
Classical music as a special form of culture has been widely defined within an ideological and social sphere in people's everyday life. A particular form of power structure has encouraged individual musicians or music events organizers to re-think the relationship between the governmental structure and individual agencies within the local music sphere. It has become clear that musical exercise is not simply invented by individual musicians or individual music organizations, but through their political cultural sphere and through society. This paper discusses the nature of democracy over classical music and explores classical music in the context of culture public sphere by theoretically reflecting the notion of public sphere by Habermas, and argues that the policy for classical music is all about bringing democracy to the local public, but, on the other hand, the local public still have concerns on whether local government really takes the necessary steps to make democracy widely available for all forms of music organizations and for everybody in the cultural sphere. The papers also discusses how the culture democracy exercise at a local music level, and explores that music education policy system together with an effective musical education curriculum should also play a positive role in addressing such concerns.
\end{abstract}

Keywords: Politics of Culture and Arts, Cultural Sociology, Music Education Policy, Habermas.

Como a música clássica está inserida em uma esfera pública de cultura?

Resumo: A música clássica como forma especial de cultura tem sido amplamente definida dentro de uma esfera ideológica e social na vida cotidiana das pessoas. Uma forma particular de estrutura de poder incentivou músicos individuais ou organizadores de eventos musicais a repensar a relação entre a estrutura governamental e as agências individuais dentro da esfera musical local. Torna-se claro que o exercício musical não é simplesmente inventado por músicos individuais ou organizações individuais de música, mas através de sua esfera política cultural e através da sociedade. Este artigo discute a natureza da democracia em relação à música clássica e explora a música clássica no contexto da esfera pública da cultura, refletindo teoricamente a noção de esfera pública por Habermas e argumenta que a política de música clássica consiste em levar a democracia ao público local, mas, por outro lado, o público local ainda tem preocupações sobre se o governo local realmente toma as medidas necessárias para tornar a democracia amplamente disponível para todas as formas de organizações de música e para todos na esfera cultural. O artigo também discute a forma como a democracia cultural se exercita em um nível de música local e explora que o sistema de políticas de educação musical junto a um currículo de educação musical efetivo também devem desempenhar um papel positivo no enfrentamento de tais preocupações.

Palavras-chave: Política de Arte e Cultura, Sociologia da Cultura, Política de Educação Musical, Habermas.

\section{Classical music and its relevance to culture public space - Classical music and cultural consumption}

Our identity is often made up by our consumption of goods, and our class difference is constructed through consumption; we become what we buy. Furthermore, BOURDIEU (1986) states that cultural capital is distributed in such a way those social groups have different capacities to invest cultural value in symbolic goods. We can take this line further, for instance, if we buy goods that have been classified as 'high arts' or 'high culture' for many years, so we will make a difference to our class compared to those who prefer consuming 'low arts' products. So, the question here is what kind of social element determines our cultural choice?

Should a specific form of culture (for example, classical music) be treated simply as a kind of commercial product in the current market rather than in the context of aesthetic enjoyment, the production and reproduction of life, intellectual capacities, and the creation of non-commodity use values? Yet, we should not simply turn cultural policy away from power and from market forces. The question to be raised here is what is the relationship among cultural policy, cultural industry and the market mechanism in relation to the issues on individualism and cultural consumption? 
For instance, McGUIGAN (2004) says that "for Adorno and Horkheimer, commodity exchange and serial production signaled the degeneration of culture under monopoly capitalism. The products of the cultural industries were formulaic and repetitive; and, they espoused pseudo-individualism” (McGUIGAN, 2004: 122). The message of the cultural industry was that everyone could achieve personal happiness through commodity consumption while individualistic values were promoted, and individualism was effectively suppressed. Adorno and Horkheimer (1979) state, "Whereas today in material production the mechanism of supply and demand is disintegrating, in the superstructure it still operates in the rulers' favour" (ADORNO and HORKHEIMER, 1979:133). The consumption of culture for most consumers most of the time has nothing to do with public subsidy; it is a side show compared to the main show, the performance of market-oriented cultural industries and mass-popular consumption (GARNHAM, 1990). Especially during the 1980s, the combination of cultural populism and free market economics appeared in British society, when the Thatcher government transformed Britain from a European social democracy into a free-market economy (HOGGART, 1995).

Yet, while classical music as a special form of culture has been widely defined within an ideological and social sphere in people's everyday life, because it is currently enjoyed by a narrow band of people it needs to be subsidized. In order to survive, people take various different views, some realizing that if subsidies were not available, classical music would be lost, whereas culture normally has been seen as something sustained by a popular consumer market.

Some of the areas have popular iconic figures, for instance, those individual artists and musicians who have played classical music, who cross the divide, who make classical music popular (or widely popular) by offering a mixed presentation. Nevertheless, it is still very difficult for orchestral music to make that transaction; it is more likely to be made by the individual.

While the consumer is pictured as the liberated single individual choosing from among the goods on offer, the musicians and their associates are essentially engaged in a kind of struggle to somehow 'resist' or 'appropriate' something generated by larger political forces and institutions, which are, in a sense, external to them. Hence the strategy of marketized popular culture and state-driven high culture ends up with public authorities trying to make up for the market. Again, the logical conclusion to this view is the reaffirmation of ideas of consumer sovereignty and class-based distinctions. By thinking in these binary terms, questions of critical cultural democratization are banished from more public forms of reflection. Yet, we need to fully recognize the role that class currently plays in the discursive and cultural construction of classical music.

\section{Classical music and Class distinction}

Sociologically, the approach of consumption has always been associated with the patterns of inequality and social differentiation, with the consumer reproducing their class position (BOURDIEU, 1984). Bourdieu further (1986) argues that the classical classification system is rooted in the class system. Bourdieu offers us a 'three-zone' model of cultural tastes: 'legitimate' taste, 'middle-brow' taste and 'popular' taste. Those tastes correspond to educational level and social class; in short, it is the beginning of a model of class life-styles (JENKINS, 1992).

Yet, it is not hard to see that Bourdieu's position is based on a vision of humanity that art rejects; he argues that taste is based on an aversion to the "facile," by which he me- 
ans the immediate, the bodily, and the simple (JOHNSON, 2002). This is further illustrated in Bourdieu's (1986) demonstration of how class distinctions are reinforced by the criteria for the selection and presentation of food that have nothing to do with its nutritional value. Arguably, classical music has served as a tool of class distinction, but can this kind of ideology provide all the evidence for our cultural choice? It is often claimed that classical music is different; this exemplifies the inadequacy of a theory that never confronts musical works themselves.

Yet, there is a certain connection between musical characteristics and social groups; in other words, social categories do play an important role in people's musical choices. But, why are musical choices mechanically determined by a social base; in other words, why can only certain forms of music be enjoyed by certain social groups? An ideology of promoting musical complexity has been simply left behind by both the public and by music participators. For instance, certain social categories, such as class distinction, have been understood with a pervasive concern with social identity during 1990s, but, in this new century, how is musical choice located within this framework of social identity and how are certain forms of music associated with an idea of class distinctions?

There are diverse voices, such as Richard HOGGART (1995), who was beginning to mount a critical appraisal of the traditional division between high arts and popular culture and call attention to the depoliticizing effects of the established cultural consensus. However, such lines of criticism had relatively little purchase on the policies of the mainstream political left, for whom the cultural agenda was mainly a matter of disseminating official culture to the public in general (WILLIAMS, 1979; HEWISON, 1987).

The proliferation of taste cultures, the shift from class-based politics to the so-called politics of identity (KEITH and PILE, 1993), and the growing availability of commercial cultural products were just some of the elements in a profound transformation taking place in the cultural sphere, serving to break down even further the traditional hierarchies and boundaries between different forms of cultural expression (McGUIGAN, 1996).

Again, the notion of class system and cultural capital has been linked with education. For instance, according to REAY (2004), Bourdieu clarified school success by taking into account the amount and type of cultural capital inherited from the family milieu rather than judging merely by measures of individual talent or achievement:

The notion of cultural capital initially presented itself to me, in the course of research, as a theoretical hypothesis which made it possible to explain the unequal scholastic achievement of children originating from different social classes by relating academic success, i.e., the specific profits which children from the different classes and class fractions can obtain in the academic market, to the distribution of cultural capital between the classes and class fractions. (BOURDIEU, 1986: 243)

So, to recognize the diversity within culture is crucial in terms of judging cultural value. In other words, cultural practitioners and the public should adopt a liberal view towards understanding cultural value, while a liberal attitude towards cultural diversity should appear among relevant cultural practitioners, especially government officers.

\section{Power and resistance at a local public sphere}

The notion of public sphere has been framed theoretically in terms of Foucault's work on power and Habermas's writing on the public sphere, and in particular, has sought to explore and develop further how governmentality has been located in the public sphere. Clearly, the Foucauldian notion of governmentality in some cultural theorists' view is sim- 
ply a kind of explanation of governance as a form of rule. For instance, Bennett focuses on questions about the role of the critical intellectual, the nature of state power and bureaucracy, and the function of culture (BENETT, 1998).

Yet the state power in a local cultural public sphere was seen to operate in a variety of ways, and also at the different levels such as macro, meso and micro levels. For instance, HABERMAS (1991) critically discusses the social interface between state and society, which he recognized as the "public sphere". He also valorizes the idea of the 'public sphere' as a benign force 'made up of private people gathered together as a public and articulating the needs for society with the state'(HABERMAS, 1991:176).

Within a certain kind of cultural public sphere, power can be seen to operate in different ways. As was argued in the literature review, power in the public sphere is more like the perpetual interaction between the public interest in culture and governmental dynamic operations. That power is also enabling; for instance, Danaher, Schirato and Webb state (2000), "Power produces resistance to itself, it produces what we are and what we can do, and it produces how we see ourselves and the world (DANAHER, SCHIRATO and WEBB, 2000). According to Foucault, "where there is power, there is resistance, and yet, or rather consequently, this resistance is never in a position of exteriority in relation to power" (FOUCAULT, 1976:85). Foucault's notion of power is a complex concept and involves a set of relations between individuals, different groups and various areas of society that changes with circumstances over time. On the other hand, power is not completely negative and should not be seen only in terms of working to repress or control people; it is also highly productive (DANAHER, SCHIRATO and WEBB, 2000). So, here we can understand that power is also about empowering and enabling and about promoting resistance.

Yet, despite such concerns, the status of resistance might also be linked to or, in other words, be tied up with the particular forms of resistance, and those particular forms of resistance may also inform us about the forms of power that they are competing with. According to Habermas, the notion of a public sphere also includes a sphere that will encourage a kind of exercise between the private opinion of all individuals' everyday life in society and the exercise of power by the state. Further, it includes a public and social sphere where individuals are gathering together to somehow express their opinions and to perform against the unreasonable and domineering form of social power.

To some extent, the governmental political structure determined the local musical agencies' movement, but rather than a negative relationship between the governmental structure and individual agencies in the local cultural sphere, a positive relationship is urgently needed. In other words, a more effective strategy needs to be devised in terms of transferring individual action into collective efforts and then becoming more organized. The following diagram may indicate how a detailed strategy can be devised for the purpose of transferring individual action to collective efforts and then becoming more organized.

When the public space expands to encompass individuals' actions, public opinion can be translated into a decision to become more organized and then institutionalized. For instance, individuals may get together to express their opinions. But how such a transformation can be institutionalized and be made more permanent by the state? Such a process of empowerment for cultural producers can be pursued only if a neoliberal cultural strategy is rejected. Neoliberalism increasingly reaffirms classical music as an elite practice. The practice of cultural democratization requires an active social state encouraging citizens to act as cultural border crosser helping them gain access to the relevant skills, knowledge and dispositions to engage in classical music as active listeners and producers. This would require a change not only in the arts, but also in the educational policy that has down-graded 
music education and sought to impose a central educational strategy around standardized testing and traditional methods of learning.

\section{Classical music reflecting local public value}

It may be worth asking why we should be interested in 'public opinion' in cultural and music policy. The reason might be that hearing the public voice is a central ritual of a democratic society, and the purpose of having a public sphere is to listen to the public's needs and voice. For instance, Habermas's notion of the public sphere also discusses a sphere that will encourage a kind of exercise between the private opinions of all individuals' everyday life in society and the exercise of power by the state.

Further, from a Habermasian point of view, the fundamental position on cultural policy is underpinned by an account of a democratic society, so the public could decisively influence the condition of culture. Culture in this respect should promote democratic and civic values and encourage participation in the dominant institutions in society. The crisis of culture from a democratic perspective emerges when the market displaces public values.

Yet, the arts and music policy are always linked with the city departmental plan for leisure and community services and with the key corporate policies from the city council. In particular, according to local needs, the question is whether the local councils together with East-Midlands Arts have played a very important and distinctive role to support local music activities at both meso and micro levels in terms of promoting democratic values. Therefore, what role has public opinion played in the national and regional cultural policy making-process in the local public sphere?

Yet, to some extent, the conflicts between individual music organizations and local government on funding issues show that the small associations have been taken into account. The public voice needs to be more of a collective voice, so it can be heard and thus bring about the desired result in the relevant organization. This is why public opinion (in other words, individuals' initiatives) at the micro level should not be treated as an important fact without the cumulative effect on cultural policy-making at the macro level or at a state level.

This would necessitate what we might call a double-sided process of democratization. Here, the wider public sphere would need to reject polices of neoliberalism for an empowering cultural state while at the same time local musicians and educational initiatives would need to follow a strategy of empowerment. Such a strategy would fuse together a Foucauldian approach (precise investigation of cultural strategies and polices) and a Habermasian approach (the radical democratization of music), but would take them further by seeking to make classical music an 'ordinary' as well as a genuinely popular practice.

\section{Culture democracy at a local music level: classical music education and public culture rights}

In contemporary society, a notion of cultural democracy has often been understood as supporting traditional culture and multiculturalism with democratic attitudes towards a broad definition of aesthetic value. Arguments over cultural policy point out a fundamental contradiction about the nature of democracy. The impulse that motivates public cultural policies is primarily democratic; it is about giving universal access to what are deemed to be unique cultural practices. However, these practices are often inaccessible in a deeper sense. For instance, JOHNSON (2002:24) argues, 
In the case of the high arts and the classical music world, most of the works are often prized precisely because of their high degree of sophistication within a particular tradition, something that tends to prevent such works from being immediately understood or enjoyed by the general public.

A traditional ideology of culture with a democratic attitude needs to be understood by the cultural authority. Yet, cultural democratization in some ways is an expansion of cultural diversity. Moreover, under the umbrella of market forces, cultural diversity presents a risk of fragmentation. Cultural democracy requires not just diversity, but respect as well. However, do a plural form of cultural expression and the development of self-respect and esteem really share all the democratic values in the British context at a local level?

Here it can be argued argue that there is no need to assume as do the political right that cultural democratization will lead to a reduction in cultural values or quality. Empowering cultural producers at the local level through empowering cultural polices and, of course, a different approach within education, will mean that quality is maintained while classical music becomes a 'common' practice.

Education has frequently been treated as a collective choice in the social legislation. The question is, do education systems express the aspiration of a society and associate with social reality? Those who teach music classes in schools or those who teach a musical instrument have realized it is becoming more difficult to defend the relevance of classical music in the current multicultural society. So, what is the purpose of music education? Should a music education policy focus only on making classical music accessible for its own people, or should music education policy encourage making classical music accessible for everybody? Taking the UK for example, according to the School Music Curriculum in the UK, "all pupils, from 5-14, have a statutory entitlement to music education in class.

Further, HARGREAVES, MARSHALL and NORTH (2003) point out that music education is changing very rapidly in the UK, as in many other countries, as a result of rapid social and technological change. The following questions have been raised in terms of the rapid changes: "What should be taught and learnt at school? What is taught and learnt out of school? How much attention should be paid to instrumental tuition? What are the modern-day roles of conservatoires, universities, and community organizations in music learning?" (HARGREAVES, MARSHALL and NORTH, 2003:147). However, others have given serious thought to how to use the positive results of the rapid change to demonstrate the purpose of music education. Classical music has always been displayed as a social practice, but, the reality is that those who have always engaged in classical music activities have always practiced on their own. It is not hard to see that the reason for the failure of the music education system is that classical music is still being seen as a form of elitism.

There is a misunderstanding of how to locate classical music in the big picture of multiculturalism and how to introduce a multicultural music education into the music curriculum. As a descriptive term, 'multicultural' refers to the coexistence of unlike groups in a common social system (PRATTE, 1979: 6). In this sense, 'multicultural' means culturally diverse.

Yet, as ELLIOTT (1989) states, music education offers a unique chance to make the goals of dynamic multiculturalism a reality. Most discussions of multicultural music education tend to focus where the light is best: on the elements of world music, on the cultural contexts of musical 'objects', and on curriculum planning and implementation. As a result, several key concepts in multicultural music education remain hidden in the darkness of critical neglect.

There is no doubt that under this ideological umbrella of multiculturalism, the 
purpose of a music education is to help individuals develop their aesthetic experience and understanding by exercising their power of discrimination. On the one hand, the government does support music education in the way that they think will fit into some kind of social target (such as using music events to help children from poor areas in the region). However, the government and LEAs have little interest in encouraging young children's personal and creative development through music education. The reason behind this is that, for instance, TOMLINSON (2001) points out that "at the end of the twentieth century, education in England remained a major agent in the reproduction of a social division of labour, and social class, race and gender remained reliable indicators of individual levels of economic poverty or prosperity (TOMLINSON, 2001:261). The local government's plan on public expenditure for music education is to concentrate on some kind of social purposes that will feed into both central and local governments' social agenda. It is not intended that the music education team will receive explicit funding from the councils for courses that cater for children's musical interests.

As EVERITT (1997) discusses, the local authorities abolished one-third of their advisory posts during 1980s and 1990s. Furthermore, the Education Act allows LEAs to charge for instrumental provision if it is for an individual or for small groups of up to four pupils. Anthony Everitt's report also shows that the budget for instrumental music that has been passed down from the LEAs to schools has decreased from $70 \%$ to $63 \%$, while the average hourly fee rate has doubled. Thus, it is easy to see that the music education policy has potentially damaged the provision of instrumental teaching in schools.

Multiculturalism versus traditionalism: do we need an effective classical music curriculum? The notion of a deliverable core music curriculum is set against personal development, instruction against discovery, and public performer against private self-development. Yet, youth orchestras in the UK have always played a positive role in British music education history. For instance, an important consequence was the emergence of youth orchestras, which play to high standards and ultimately give children the future opportunity to join a professional orchestra. Therefore, a positive policy needs to be encouraged to support the regional youth orchestras' development. However, some policy-makers still think participation in classical music is elitist. Is it because only parents with sufficient financial capital are likely to fund their children to take part in such activities? Yet, as JOHNSON (2002) argues, state education policy somehow reinforces the social division it pretends to oppose.

Hence, the issue is less multiculturalism versus traditionalism and more a question of state support, cultural empowerment and educational effect to foster new skills as opposed to government cuts and the narrowing of educational agendas that are increasingly focused on league tables and passing exams. The argument that classical music is opposed to multiculturalism is a veil obscuring the real issues at stake in respect of the promotion of the practice of classical music for everyone. Of course once young people and learned a particular instrument they may then use this knowledge to cross other cultural boundaries. However the most pressing issue in respect of music policy and education remains the cultural empowerment of young people and the promotion of complex forms of literacy in respect of musical cultures that is not simply restricted to the consumption of popular music for the many and the playing of classical music by the educated middle class.

A "child-centred" model has been replaced by a kind of ideology of letting students taste what instrumental learning is like, but not providing enough teaching resources to support its continuity. In comparison with the teacher-centred model, the child-centred model has been discussed by some scholars. For instance, HARGREAVES, MARSHALL and 
NORTH (2003) state that, on the one hand, arts educators in some countries, such as Korea, Japan, and China, aim to develop the character of pupils. On the other hand, they point out the Indian guru-shishya system, for example, which is very heavily teacher-centred: it adopts an apprenticeship model in which the pupil (literally) sits at the feet of the teacher and learns the philosophy, traditions, and techniques of the music over months and years (HARGREAVES, MARSHALL and NORTH, 2003:156). So, they argue that this teacher-centred model stands is the opposite of the highly pupil-centred 'creativity' movements that exist in the UK. It seems that a consistent music education curriculum is vital to complete this transmission process.

To conclude, musical exercise is not simply invented by individual musicians or individual music organizations, but through their political cultural sphere and through society. The classical music policy is all about bringing democracy to the local public, but, on the other hand, the local public still have concerns on whether local government really takes the necessary steps to make democracy widely available for all forms of music organizations and for everybody in the cultural sphere. Culture democracy is exercised at a local music level by enhancing classical music education and public culture rights. Music education policy system together with an effective musical education curriculum should play a positive role in addressing such concerns.

\section{References}

ADORNO, T.W. and HORKHEIMER, M (1979) The Culture Industry: Enlightenment as Mass Deception, Dialectic of Enlightenment. London: Verso.

BENETT, T. (1998) Culture: A Reformer's Science. London: Sage.

BOURDIEU, P. (1984) Distinction: A Social Critique of the Judgement of Taste. London: Routledge. BOURDIEU, P. (1986) The forms of capital, in: John G. Richardson (ed.), Handbook of Theory and Research for the Sociology of Education. New York: Greenwood Press.

DANAHER, G., SCHIRATO, T and WEBB, J. (2000) Understanding Foucault. London: Sage.

ELLIOTT, J.D. (1989) Key Concepts in Multicultural Music Education. International Journal of Music Education, 13: 11-18.

EVERITT, A. (1997) Join in: an Investigation into Participatory Music. London: Calouste Gullenkian Foundation.

FOUCAUlT, M. (1976) The History of Sexuality: Volume I: The Will to knowledge, London: Penguin.

GARNHAM, N. (1990) Capitalism and Communication-Global Culture and Economics of Information. London: Sage.

HABERMAS, J. (1991) The Structural Transformation of the Public Sphere. Massachusetts: MIT Press.

HARGREAVES, D.J., MARSHALL, N. \& NORTH, A.C. (2003) Music education in the 21st Century: a Psychological Perspective. British Journal of Music Education, 20(2), 147-163.

HEWISON, R. (1987) The Heritage Industry-Britain in a Climate of Decline. London: Methuen.

HOGGART, R. (1995) The Live we Live now. London: Chatto and Windus. 
JOHNSON, J. (2002) Who needs Classical music? Culture Choice and Musical Value. Oxford: Oxford University Press.

JENKINS, R. (1992) Pierre Bourdieu. London: Routledge.

KEITH, M. and Pile, S. (1993) Place and the politics of identity. London: Routledge.

McGUiGAN, J. (1996) Culture and the Public Sphere. London: Routledge.

McGUIGAN, J. (2004) Rethinking Cultural Policy. Milton Keynes: Open University Press.

McGUIGAN, J. (2006) Richard Hoggart: Public Intellectual, International Journal of Cultural Policy, 12(2): 199-208.

PRATTE, R. (1979) Pluralism in Education: Conflict, Clarity and Commitment. Springfield: Charles C. Thomas.

REAY, D. (2004) Education and Cultural Capital: The Implications of Changing Trends in Education Policies, Cultural Trends, 13(2): 73-86

TOMLINSON, S. (2001) Education Policy, 1997-2000: the effects on top, bottom and middle England, International Studies in Sociology of Education, 11(3): 261.

WILLIAMS, R. (1976) Keywords: A Vocabulary of Culture and Society. London: Fontana.

Juan Wang is currently a research associate of International Gender Studies Centre at Oxford University. She has been trained as a pianist from a young age, and developed a strong passion for classical music. This passion has led her to further engage with research into classical music. She obtained her MA in Education and PhD in Sociology from Nottingham University in the UK. Following her PhD, Dr. Wang has worked as a researcher with the Director of International Gender Studies Centre on a DFID-funded project -'Women's Empowerment in Muslim Contexts (WEMC)' at the Oxford Department of International Development (ODID), Queen Elizabeth House at Oxford University. Dr. Wang has held senior tutor position at Hugh Stewart Hall at Nottingham University, and also served as a visiting lecturer at Nottingham Trent University in the UK. She has published over 15 journal articles and conference papers in the areas of ethnomusicology, cultural sociology and gender studies. She currently serves as a journal referee for International Journal of Journalism and Mass Communication (Premier Publishers), and the Journal of Digital Scholarship in the Humanities (Oxford University Press). Her recent research activities involve writing and publishing a book entitled "Governmentality and Public Sphere in Cultural Policy Studies" (Lambert Publisher, Saarbrücken, ISBN-13: 978-3848489718), and giving an invited lecture on "Theoretical and Empirical Reflection in Creative and Cultural Industry" in Shenzhen Graduate School of Harbin Institute of Technology, and Arts Forum of the China 11th (Shenzhen) International Culture Industries Fair in 2015. 